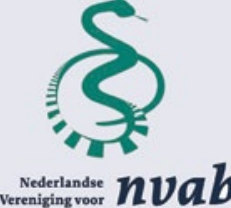

Kwaliteitsbureau

NVAB

Postbus 2113

3500 GC Utrecht

(030) 2040620

nvab@nvab-online.nl www.nvab-online.nl

\section{Algemene Ledenvergadering}

We kijken inmiddels terug op een geslaagde digitaal gehouden ALV in juni, ruim 100 leden uit 7 verschillende landen waren ingelogd. Naast meer huishoudelijke punten als de verlening van decharge voor het gevoerde financiële beleid in 2019, werd door de leden ook het standpunt Delegatie van taken door de bedrijfsarts en supervisie aangenomen. Net als bij u, blijft de coronacrisis van invloed op de activiteiten binnen de NVAB. Zo is er hard gewerkt aan de vierde en vijfde coronanieuwsbrief en is 18 juni het standpunt spreekuurcontacten uitgebracht. Op het moment van schrijven is de basisregel voor spreekuurcontact nog steeds Werk zoveel als mogelijk vanuit huis en houdt dus spreekuur op afstand. Maar goede zorg, advies of oordeelsvorming kan met regelmaat niet zonder face-to-face-contact. Mocht een spreekuur op afstand niet geschikt zijn, bijvoorbeeld omdat je als bedrijfsarts daarmee onvoldoende informatie krijgt om tot een verantwoord advies te komen, dan verdient een fysiek spreekuurcontact de voorkeur, mits dat veilig gebeurt. Er is ook ander nieuws te melden. Zo is begin juli de richtlijn Nachtwerk en Gezondheid verschenen en volgde Frederieke Schaafsma op 1 juli Carel Hulshof op als bijzonder hoogleraar Arbeids- en Bedrijfsgeneeskunde. Namens bestuur en bureau van de NVAB, stay safe and keep well.

\section{4e en 5e editie kennisnieuwsbrief COVID-19}

Het coronavirus (SARS-CoV-2, beter bekend onder de ziektebenaming COVID-19) roept veel vragen op. Bij werkgevers en werknemers, maar ook bij de arboprofessionals die hen met raad en daad terzijde staan. NVAB en NCvB hebben het initiatief genomen voor de uitgave van een kennisnieuwsbrief, die antwoord geeft op de meest gestelde vragen. Hiermee dragen de samenwerkende deskundigen en beroeps- en brancheverenigingen voor gezond en veilig werken (NVAB, NCvB, NVVA, NVVK, BA\&O, V\&VN, OVAL en KOM) bij aan zo goed mogelijke kennisdeling. Dit initiatief is afgestemd met het RIVM en het ministerie van SZW ondersteunt het initiatief financieel. De nieuwsbrieven zijn te vinden op www.kiza.nl. In mei en juli zijn de 4 e en 5 e editie van deze kennisnieuwsbrief verschenen, met antwoord op in totaal 26 veel gestelde vragen, zoals: hoe kunnen werknemers veilig op vakantie naar het buitenland en wat is er nodig voor herstel en re-integratie van mensen die erg ziek zijn geweest van COVID-19? Voor arboprofessionals die vragen hebben over het coronavirus, is een centraal loket ingesteld. Vragen kunnen per e-mail worden ingediend bij corona@beroepsziekten.nl

\section{Richtlijn Nachtwerk}

Dat nachtwerk kan leiden tot slaapproblemen en vermoeidheid zal niet verrassend zijn. Er kunnen echter ook andere gezondheidsproblemen optreden met serieuze gevolgen op de lange termijn. Blootstelling aan nachtwerk betekent bijvoorbeeld ook een verhoogd risico op diabetes en hart- en vaatziekten. Het is daarom belangrijk om na te gaan of het echt noodzakelijk is werkenden bloot te stellen aan nachtwerk, of dat nachtwerk vermeden kan worden. Dat is de eerste stap volgens de arbeidshygiënische strategie. Of, zoals de aanbeveling in de richtlijn zegt: Adviseer de werkgever om geen of zo min mogelijk gebruik te maken van nachtwerk, en alleen als daarvoor gegronde redenen zijn. In de nieuwe NVAB-richtlijn Nachtwerk en Gezondheid staat welke onderwerpen ten aanzien van preventie in de RI\&E thuis horen, welke preventieve organisatorische maatregelen geadviseerd kunnen worden en welke preventieve adviezen er zijn voor individuele werkenden. Ten slotte worden individuele begeleiding en interventies beschreven voor, als een werkende via een PMO, open spreekuur of verzuimspreekuur bij jou als bedrijfsarts komt. Met name het samen met de werkende beslissen over het wel of niet doorgaan met nachtwerk krijgt daarin ruime aandacht. Dit is uitgewerkt in vifftien gerichte vragen aan nachtwerkers.

\section{Agenda}

1 oktober $2020 \quad$ Extra ledenbijeenkomst

2 oktober 2020 Maak werk van Kwaliteit -

Slotsymposium Kwaliteitstafel

Bedrijfs- en Verzekeringsgeneeskunde

Op 31 mei 2018 ging de Kwaliteitstafel van start voor een periode van twee jaar. Het doel van de Kwaliteitstafel was om de instroom in de beroepen van bedrijfs- en verzekeringsarts te verhogen door het bevorderen van duurzame kennis- en kwaliteitsontwikkeling. De opdracht was ook om een uitvoerbaar en gedragen model voor de structurele financiering van het kwaliteitsbeleid te ontwikkelen. Tijdens het slotsymposium presenteren we het advies dat aan de staatssecretaris wordt overhandigd en bespreken we alle activiteiten en producten die in de afgelopen periode tot stand kwamen.

\section{2 november 2020 Bedrijfsgeneeskundige Dag} De Bedrijfsgeneeskundige Dagen waren oorspronkelijk gepland op 14 en 15 mei. Vanwege de maatregelen ter bestrijding van het coronavirus konden die toen niet doorgaan. Je kunt je nu op 2 november onderdompelen in een grote BG-dag op Papendal, Arnhem. Ook nemen we afscheid van Carel Hulshof als bijzonder hoogleraar Arbeids- en bedrijfsgeneeskunde. Het programma voor deze dag volgt.

\section{0 december 2020 Afscheidssymposium Kees van Vliet en najaars-ALV}

Het symposium De Bedrijfsarts 2040 ter gelegenheid van het terugtreden van Kees van Vliet als directeur van de NVAB is verplaatst van 2 april naar 10 december, van 15.30 tot 17.30. Voorafgaand zal tussen 13.00 en 15.30 de najaarsALV worden gehouden.

\section{7-28 mei $2021 \quad$ Bedrijfsgeneeskundige Dagen} 2021

Gijsbert van Lomwel, directeur 


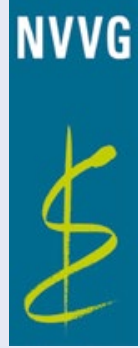

Secretariaatsbureau NVVG

Domus Medica

Postbus 24095

3502 MB Utrecht

(030) 6868764

secretariaat@nvvg.nl www.nvvg.nl

\section{Terug van vakantie}

$\mathrm{Nu}$ iedereen weer (bijna) terug is van een vakantie - of daaraan in ieder geval gedacht heeft in de eigen tuin - is er één ding niet veranderd: het coronavirus is nog steeds onder ons. Binnen enkele maanden zijn we gewend geraakt aan een nieuwe werkelijkheid die meer en meer het karakter van een blijvend iets gekregen heeft. Ons werk ziet er anders uit dan vóór maart. We werken meer thuis, fysieke beoordelingen zijn voor een deel vervangen door telefonische contacten of een van de beeldbelvarianten. Het heeft ons bevestigd - of herbevestigd? - dat een fysieke beoordeling niet altijd de gouden standaard hoeft te zijn. Maar toch, als beroepsgroep moeten we ervoor zorgen dat we onder druk van een werkgever of opdrachtgever die vooral quick wins ziet, de kwaliteit van de verzekeringsgeneeskundige beoordeling scherp voor ogen blijven houden. Wij als bestuur zullen dat doen in externe overleggen maar $\mathrm{u}$ als (verzekerings)arts hebt ook en vooral een eigen professionele verantwoordelijkheid. En als $u$ daarvoor een werkgever of opdrachtgever tegen de haren in moet strijken, dan is dat maar zo. Het klinkt mogelijk ernstiger en dramatischer dan het is maar mede gezien het alsmaar aanhoudende tekort aan verzekeringsartsen, de grote hoeveelheid beoordelingen die gedaan moeten worden en de daardoor ook op onze schouders neergelegde politieke druk, staat de toekomst van ons vak wel enigszins onder druk.

\section{Kennisagenda Bedrijfs- en Verzekeringsgeneeskunde}

Het bestuur is trots op de werkgroep Kennisagenda en haar projectleider Heike Jansen. Er is een puike kennisagenda samengesteld. De werkgroep heeft veel werk verzet en dit heeft geleid tot een mooi product met veel dwarsverbanden. Het bestuur heeft de Kennisagenda bekrachtigd en heeft het verder passend gevonden om de kennisagenda als eerste aan de commissie Wetenschap aan te bieden. In een van de komende nummers van TBV zal Heike Jansen $u$ meer vertellen over de Kennisagenda.

\section{Najaarsledenvergadering}

Het zal u niet verbazen dat ook de najaarsledenvergadering dit jaar digitaal gaat plaatsvinden. Met een al vervallen voorjaarsvergadering is het contact tussen leden en bestuur daarom dit jaar erg schraal. De vergadering wordt gehouden op 8 oktober 2020, tussen 15.00 en 17.00. Het bestuur zal wel bij elkaar zijn, de daarvoor gereserveerde ruimte is groot genoeg om de coronaregels geen geweld aan te doen. Er zal een moderator aanwezig zijn om het soepel te laten verlopen. Een aanvullend programma, gebruikelijk bij de ledenvergaderingen, zal er niet zijn. Dat is een van de vele gevallen van 'jammer maar het is niet anders'.

\section{Verzekeringsgeneeskundige Dagen.}

Als ik dit schrijf - begin augustus - is het nog niet duidelijk of en hoe de Verzekeringsgeneeskundige Dagen doorgang zullen vinden. De gebruikelijke driedaagse variant met een avondprogramma op woensdag, een Engelstalige dag op donderdag en een afsluitende Nederlandstalige dag zal het zeker niet zijn. Recent heeft de congrescommissie een korte enquête uitgezet met als voorstel een fysieke bijeenkomst voor een zeer beperkt aantal leden (ongeveer honderd) en voor het overige de mogelijkheid om het programma online te volgen. Wat het gaat worden is mogelijk al bekend bij verschijnen van dit blad.

\section{Agenda}

8 oktober 2020

(online)

Najaarsledenvergadering

4-6 november 2020

te Almere

Verzekeringsgeneeskundige dagen

16-18 september

2021 te Basel

UEMASS-Congres

Hans de Brouwer, secretaris 